\title{
Growth, reproduction and food habit of an invasive species of Carassius auratus in the Al-Diwaniya River, Middle of Iraq
}

\begin{abstract}
Abdul-Razak M. Mohamed*
Department of Fisheries and Marine Resources, College of Agriculture, Basrah University, Iraq

Mohanad O.A. Al-Jubouri

Department of pathology, College of Veterinary Medicine, Al-Qasim Green University, Iraq

*Corresponding author. E-mail: abdul19532001@yahoo.com

Abstract

Carassius auratus is an invasive species that has successfully established populations throughout Iraq. Unfortunately there is no information available regarding the biological properties of the species in Al-Diwaniya River, Middle Euphrates, Iraq. So growth, reproduction and food habit of $C$. auratus were investigated in this river from November 2016 to October 2017. Length groups of the fishes from 19 to $21 \mathrm{~cm}$ were prevailing the catch and formed $30.8 \%$. Length-weight relationship was calculated as $W=0.013 L^{3.129}$ for all individuals, with allometric growth. The condition of the fish increased in early spring. The maximum age recorded was 5 years with $30.1 \mathrm{~cm}$. The parameters to the von Bertalanffy growth curve fitted to mean total lengths at age were $L \infty=43.0, K=0.225$ and $t_{0}=-0.412$. The index of growth performance $(\Phi)$ was 2.612. The unbalanced overall ratio of males to females was 1:3.81. Higher values of gonado-somatic index (GSI) for males and females occurred in early spring. $C$. auratus is an herbivorous, with a diet that includes algae $(52.6 \%)$, macrophytes $(22.0 \%)$, diatoms $(15.8 \%)$, crustacean $(4.8 \%)$ and aquatic insects $(4.8 \%)$. Our results highlighted basic biological aspects of the invasive $C$. auratus which can assist in fisheries management and conservation of the fish species in Al-Diwaniya river.
\end{abstract}

Keywords: Al-Diwaniya river, Carassius auratus, Food habit, Growth, Reproduction

\section{Article Info}

https://doi.org/

10.31018/jans.v11i3.2163

Received: August 21, 2019

Revised: September 2, 2019

Accepted: September 7, 2019

\section{How to Cite}

Mohamed, A.R.M. and AlJubouri, M.O.A. (2019) Parametric vis-a-vis non parametric measures describing $G \times E$ interactions for salt salinity tolerant barley genotypes in multienvironment trials. Journal of Applied and Natural Science, 11(3): $704-711$ https://doi.org/10.31018/ jans.v11i3.2163

\section{INTRODUCTION}

The crucian carp Carassius auratus (Linnaeus, 1758), a cyprinid native to Eastern Asia, is an example of a non-indigenous fish species that has successfully established populations throughout Europe, North and South America, New Zealand and Australia (Lorenzoni et al., 2010). Al-Nasiri and Shamsul Hoda (1976) listed the freshwater fish species of Iraq and referred to the presence of C. auratus for the first time in Iraqi waters, this species is considered as an unofficially introduced exotic fish to Iraq like other species, such as common carp, Cyprinus carpio, but has invaded the country in ways that are not yet been known, however, Coad (2010) mentioned that this species has been introduced throughout Iranian waters including Khuzestan waters, these fish can easily have crossed the border into Iraqi waters. C. auratus now well established and easily becomes one of the dominant species throughout the Iraqi waters such as; in Euphrates river at Al-Mussaib Power Station (AL-Rudainy et al., 2006), in southern marshes (Mohamed et al., 2008, 2012; Hussain et al., 2009), in Al-Hilla river (Al-Amari, 2011), in Euphrates river at Al-Hindyah Barrier (Khaddara, 2014), in Tigris river before Al-Kut Barrier (Abbas et al., 2017) and in Shatt Al-Arab river (Mohamed and Abood, 2017).

The biological characteristics of $C$. auratus have been carried out by some investigators in different natural waters of Iraq. Saud (2006) reported feeding habits of the species in southern marshes. Abbas et al. (2008) described length-weight, growth and mortality rates of $C$. auratus in the Euphrates river at Al-Mussaib Power Station, middle of Iraq. Al-Shami (2008) reported the fecundity and histological description for its ripe ovaries of C. auratus in Garmat Ali river. The population status of the species in restored East Hammar marsh during 2007-2008 has been investigated by AlNoor (2010). The length-weight relationship, growth, reproduction and food habit of $C$. auratus in Al-Hilla river and in Euphrates river at $\mathrm{Al}$ Hindyah Barrier have been described by Al-Amari (2011) and Khaddara (2014), respectively. Rasheed (2012) reported the length-weight relationship of $C$. auratus in Derbendikhan reservoir. 
Wahab (2013) studied food habits of the species in Al-Tharthar canal, Tigris river. Mohamed et al. (2016) investigated the growth, mortality and exploitation rates, and the yield per recruit of $C$. auratus in the Esat Hammar marsh following six years of inundation. Length frequency distribution, length-weight relationship, age, growth rate and reproductive of $C$. auratus in East Hammar marsh have been studied by Mohamed et al. (2017).

Presently there is no information available regarding the biological properties of the silver crucian carp population in Al-Diwaniya River, Middle Euphrates. This study therefore investigates some biological parameters, such as length frequency distribution, length-weight relationship, condition factor, age, growth rate, sex ratio, gonado-somatic index and food habit of silver crucian carp population in the Al-Diwaniya river and our data are compared with results from other populations.

\section{MATERIALS AND METHODS}

Study area: AL-Diwaniya River, Al-Qadidiyah Province is an extension of the Al-Hilla River which is a branch of Euphrates River at AlHindyah Barrier, in the middle of Iraq (Fig. 1). It is $123 \mathrm{~km}$ long, 25-30m wide and 3-5m depth. The river flows through the AL-Diwaniya city, then narrows in the districts of Sideer and Al-Hamzah and continues to flow until it fades in the district of AlRumaythah, Al-Muthanna Province. The predominant vegetation on the both banks of this locality were reed, Phragmites australis and cattail, Typha domingensis, whereas hornwort, Ceratophyllum demersum was dominant in the deeper areas. The fish fauna comprises 27 species and is dominated by cyprinids, including Carassiu carassius, Carasobarbus luteus, Leuciscus vorax, $A$. grypus, Luciobarbus xanthopterus and Mesopotamichthys sharpeyi; other common species are Planiliza abu (Mugilidae) and Oreochromis aureus (Cichlidae) (Mohamed and Al-Jubouri, 2017).

Fish sampling: Sampling was conducted monthly, from November 2016 to October 2017 from two sites (Fig. 1). Specimens were caught by means of electrofishing equipment (provides 150-300V) and three types of nets. The seine net ( $3 \mathrm{~m}$ long and $2.5 \mathrm{~m}$ depth with a $20 \mathrm{~mm}$ mesh size), gill nets (25m long with $20 \times 20,30 \times 30$ and $50 \times 50 \mathrm{~mm}$ mesh sizes) and cast net (9m diameter with $15 \times 15 \mathrm{~mm}$ mesh size). Fish were immediately preserved in ice box for subsequent analysis.

Laboratory measurements: In the laboratory, fish individually measured for total length $(T L)$ to the nearest $\mathrm{mm}$ and weighed $(W)$ to the nearest $0.1 \mathrm{~g}$. A sample of scales for aging was taken from a standard area between the lateral line and dorsal fin of the fish. Scales were cleaned with warm water and placed between two glass slides (Schneider et al., 2000). Fish was dissected ventrally and gonads were removed, weighed and examined to determine sex. The guts were removed and preserved in 5\% formalin until the contents were analyzed.

Estimation of growth: The length-weight relationship, $\mathrm{W}=\mathrm{a} \mathrm{L}^{\mathrm{b}}$ was applied (Le Cren, 1951), where $W$ is the weight $(\mathrm{g}), \mathrm{L}$ is the total length (cm), and $a$ and $b$ are constants, using data from all fish collected. The hypothesis of isometric growth (Ricker, 1975) was tested with Student's $t$ test.

The state of well-being of the fish was estimated by means of the relative condition factor $\left(K_{n}\right)$ using the following formula, $\mathrm{K}_{\mathrm{n}}=\mathrm{W}^{\prime} \mathrm{W}$ (Le Cren, 1951), where $W^{\prime}=$ the observed weight of each individual and $W=$ the expected weight using the lengthweight relationship.

The age of the fish was determined by means of the Projectina microscope, 20X. From the magnified image of the scale, total scale radius and the distance between the focus and their respective annuli were measured. The relationship between the length of fish on capture $(L)$ and the radius of scale $(S)$ was calculated from the equation: $L=a+$ b S (Bagenal and Tesch, 1978), where a is the intercept and $b$ is the slope of the regression line. Back-calculated lengths were estimated by using the following formula: $L_{n}=a+S_{n} / S$ (L-a) (Bagenal and Tesch, 1978), where $L_{n}$ is the length of the fish at age ' $n$ ', $a$ is the intercept with the axis of the abscissa of the previous regression, $S_{n}$ is the radius of the annulus ' $n$ ', $S$ the scale radius and $L$ is the length at the time of capture. Annual growth increment in centimeters was calculated for each fish collected for each year of its life using backcalculated mean length-at-age data.

The theoretical growth in length was described by the von Bertalanffy growth equation: $L_{t}=L_{\infty}\left(1-e^{-}\right.$ $\mathrm{K}(\mathrm{t}-\mathrm{to})$, where $L_{\mathbf{t}}$ is the theoretical total length at age $t, L_{\infty}$ is the asymptotic length, $K$ is the coefficient of growth and $t_{0}$ is the theoretical age at length= zero (Bagenal and Tesch, 1978). The growth curve was fitted to the back calculated mean length at age of the species by means of Beverton and Holt method (Ricker, 1975). The index of growth performance $(\Phi)$ was calculated using the equation $\Phi=\log k+2 \log L \infty$, where $K$ and $L_{\infty}$ are von Bertalanffy parameters (Pauly and Munro, 1984).

Sex ratio and gonado-somatic index: The Gonado-Somatic Index (GSI) of fish was expressed as a percentage of gonad weight (GW) to body weight (BW) for the collected specimens (De Silva, 1973):

$\mathrm{GSI}=\mathrm{GW} / \mathrm{BW} \times 100 \%$

The ratio of the number of male to female specimens was determined. Sex ratio was tested by chi square $\left(X^{2}\right)$ method. Thus:

$X^{2}=\Sigma(O-E) 2 / E \quad$.......Eq.2

Where, $\mathrm{O}=$ Observable and $\mathrm{E}=$ Expected.

Food analysis: The food analysis was under tak- 
en using the points $(P)$ and frequency of occurrence $(O)$ methods following (Hyslop 1980). The diet was determined using the index of relative importance (IRI) of Stergion (1988). This index combines the occurrence $(O)$ and points $(P)$ : $\mid R I=O \% \times P \%$ and $|R I \%=| R I / \Sigma \mid R I * 100$ ........Eq.3

All the calculations were done by using Microsoft Office Excel 2010.

\section{RESULTS}

Length frequency distribution: Figure 2 showed length frequency distribution of the catch for $C$. auratus. A total of 1136 fish specimens of the species ranging from 7.0 to $30.0 \mathrm{~cm}$ in total length were collected from the river. The highest frequency of catches belonged to the length group $19 \mathrm{~cm}$ constituting $12.9 \%$, whereas the length groups from 19 to $21 \mathrm{~cm}$ prevailed the catches and formed $30.8 \%$ of the catch.

Length-weight relationship: The graphic representation of the estimated length weight relationship is given in Figure 3. The length-weight relationship of $C$. auratus from the river based on 314 specimens ranging from 8.0 to $30.0 \mathrm{~cm}$ in total length and between 10.7 to $700.0 \mathrm{~g}$ in weight provided a good fit for $C$. auratus data as, $W=$ $0.013 L^{3.129},(r=0.957)$. The results show that in the river the species displays allometric growth $(t-$ test $=3.424, P>0.05$ ).

Relative condition factor: Monthly changes relating to the relative condition factor $\left(K_{n}\right)$ of $C$. auratus population are given in Figure 4 . The lowest condition value $(0.87)$ occurred in November, whereas the highest one (1.14) was observed in March. The monthly trend of the condition shows that the best condition is reached at the beginning of the spring and the lowest condition during au-

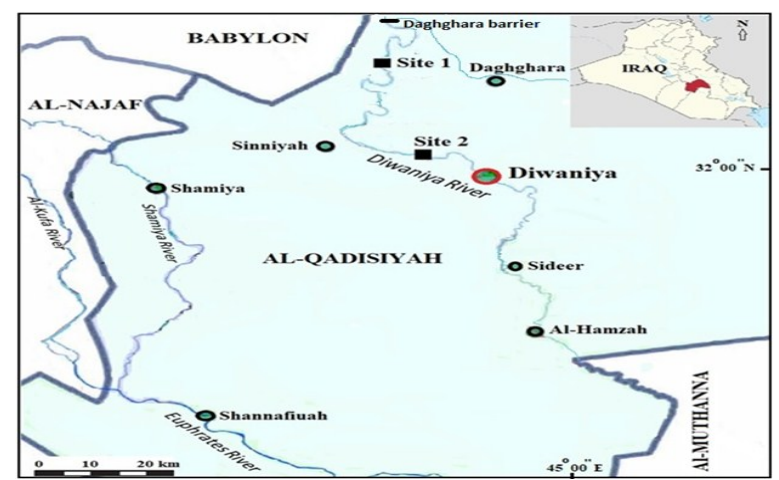

Fig. 1. Map showing the study sites in Al-Diwaniya River at 2016-2017.

tumn. The mean value of the relative condition factor in the overall sample was 0.99 .

Age and growth rate: The scatter diagram denotes the straight-line relationship between fish length (L) and scale radius (S). The relationship was expressed as: $L=1.402+2.209 * S$ and high coefficient correlation, $r=0.941$ (Fig. 5).

The back-calculated lengths at the various ages enabled us to evaluate the growth of the specimens (Table 1). The mean lengths estimated at ages 1 to 5 year were found to be $11.9,17.5,23.3$, 27.2 and $30.1 \mathrm{~cm}$ respectively. The rapid growth in length was found during the first year of life, followed by a period of slow growth rate in the rest of life.

The parameters of the theoretical growth in length of C. auratus were $\mathrm{L}_{\infty}=43.0, \mathrm{~K}=0.225, \mathrm{t}_{0}=$ 0.412 and the index of growth performance $(\Phi)$ was 2.612 .

Sex ratio and gonado-somatic index: Females giving a sex ratio (male: female) of 1:3.8 was significantly different $\left(X^{2}=115.2, P>0.05\right)$ from the expected 1:1 meaning the number of females was

Table 1. Mean observed and back-calculated total lengths of $C$. auratus during 2016-2017.

\begin{tabular}{|c|c|c|c|c|c|c|c|}
\hline \multirow{2}{*}{ Age } & \multirow{2}{*}{$\begin{array}{l}\text { No. of } \\
\text { fish }\end{array}$} & \multicolumn{5}{|c|}{ Length at age $(\mathrm{cm})$} & \multirow{2}{*}{$\begin{array}{l}\text { Length at cap- } \\
\text { tured }(\mathrm{cm})\end{array}$} \\
\hline & & 1 & 2 & 3 & 4 & 5 & \\
\hline 1 & 19 & 11.2 & & & & & 11.8 \\
\hline 2 & 22 & 11.6 & 17.4 & & & & 17 \\
\hline 3 & 28 & 12.7 & 17.6 & 23.2 & & & 21.2 \\
\hline 4 & 7 & 11.9 & 17.8 & 23.8 & 27.3 & & 44.2 \\
\hline 5 & 8 & 11.2 & 17.6 & 23.4 & 27.1 & 30.1 & 49.7 \\
\hline Mean length (cm) & & 11.9 & 17.5 & 23.3 & 27.2 & 30.1 & \\
\hline Annual increment $(\mathrm{cm})$ & & 11.9 & 5.7 & 5.8 & 3.9 & 2.9 & 30.1 \\
\hline$\%$ Growth increment & & 39.3 & 18.9 & 19.2 & 12.9 & 9.7 & 100 \\
\hline
\end{tabular}

Table 2. Growth comparison of $C$. auratus in different ecosystems.

\begin{tabular}{lllllllllll}
\hline \multirow{2}{*}{ Ecosystem } & \multicolumn{8}{c}{ Mean total length at each age (cm) } & \multirow{2}{*}{ 我 } & \multirow{2}{*}{ Reference } \\
\cline { 2 - 10 } & $\mathbf{1}$ & $\mathbf{2}$ & $\mathbf{3}$ & $\mathbf{4}$ & $\mathbf{5}$ & $\mathbf{6}$ & $\mathbf{7}$ & & \\
\hline Wanghu Lake & 7.3 & 12.6 & 16.0 & 18.7 & 23.0 & - & - & 28.6 & Zhonghua et al. (1994) \\
Euphrates river & 9.6 & 16.1 & 19.6 & 23.8 & - & - & - & 29.7 & Abbas et al. (2008) \\
East Hammar marsh & 8.5 & 13.9 & 16.5 & 20.9 & 22.2 & 25.8 & 29.5 & 32.6 & Al-Noor (2010) \\
Lake Trasimeno & 10.8 & 16.9 & 24.0 & 29.8 & 34.3 & - & - & 43.0 & Lorenzon et al. (2010) \\
East Hammar marsh & 11.0 & 17.5 & 23.1 & 27.4 & 30.4 & 33.2 & - & 42.3 & Mohamed et al. (2017) \\
Al-Diwaniya river & 11.9 & 17.5 & 23.3 & 27.2 & 30.1 & - & - & 43.0 & Present study \\
\hline \hline
\end{tabular}




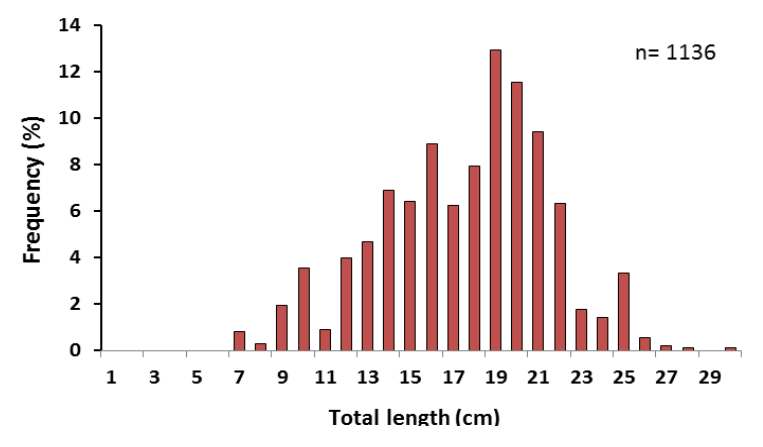

Fig. 2. Overall length frequency of $C$. auratus during 2016-2017.

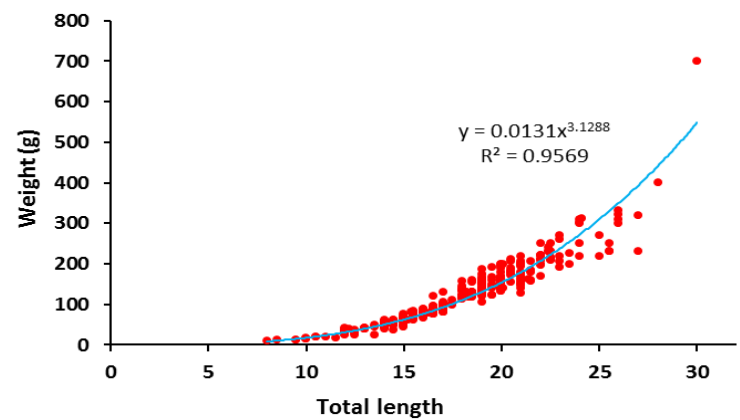

Fig. 3. Length-weight relationships of C. auratus during 2016-2017.

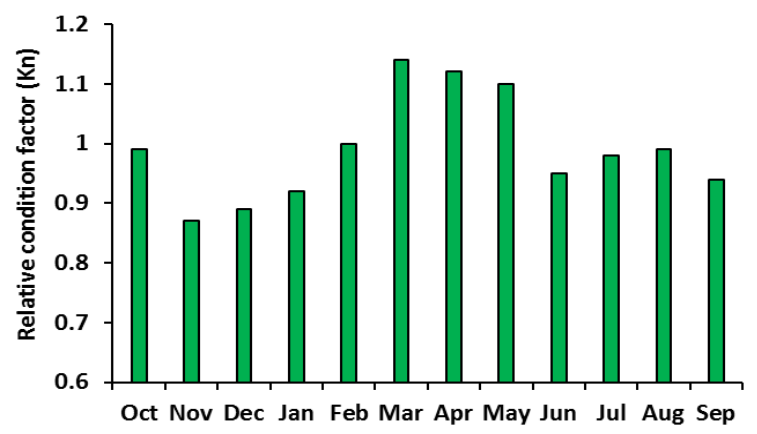

Fig. 4. Monthly variation in relative condition factor (Kn) of C. auratus during 2016-2017.

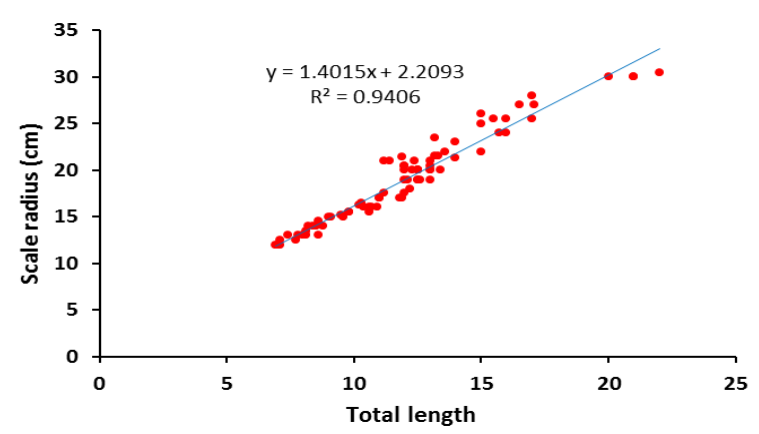

Fig. 5. Relationship between fish length $(L)$ and scale radius of C. auratus during 2016-2017.

significantly higher than males in the river. Changes in monthly values of the gonado-somatic index (GSI) of both sexes for $C$. auratus are given in Figure 6. It is observed that the lowest mean GSI values were obtained in November 0.56 for

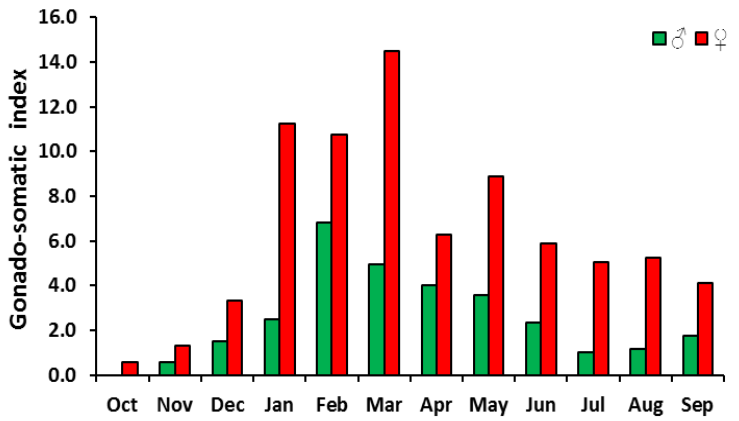

Fig. 6. Monthly variations in the GSI of C. auratus during 2016-2017

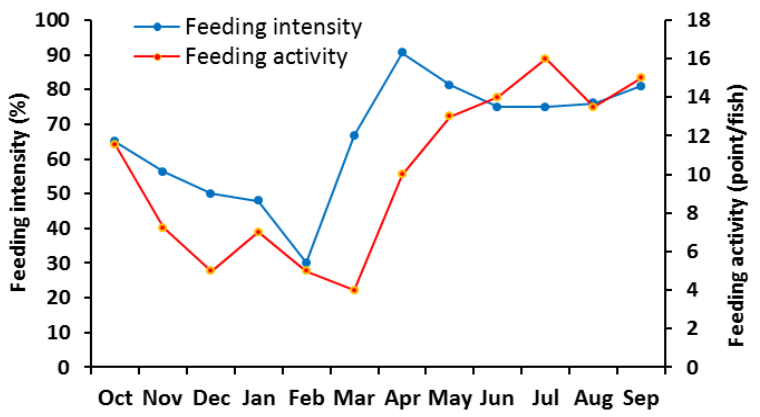

Fig. 7. Monthly variations in feeding intensity and activity of C. auratus during 2016-2017

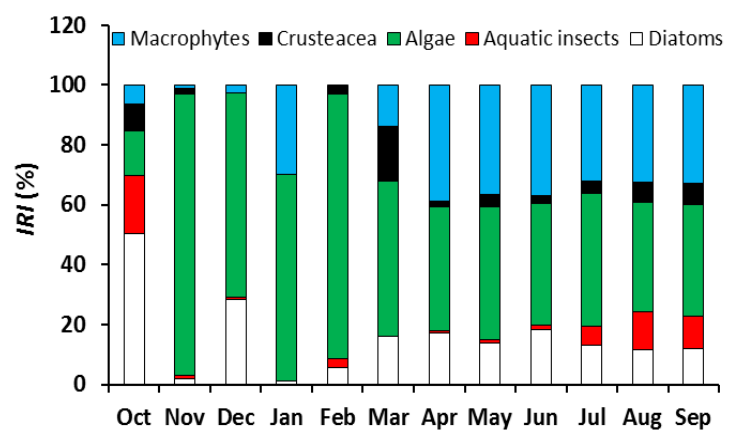

Fig. 8. Monthly changes in IRI\% of food items in the diet of C. auratus during 2016-2017

males and in October 0.57 for females. The highest mean values occurred in February 6.82 for males and in March 14.46 for females. The monthly differences between the two sexes were significant on $t$-test $(t=2.931 ; P<0.05)$.

Food habit: In this study 292 stomachs of the fishes were examined, 196 stomachs contained food items and 96 were empty representing $67.1 \%$ and $32.9 \%$, respectively. Figure (7) illustrates monthly variations in the feeding activity and intensity of $C$. auratus in the river. The feeding intensity varied from 4 point/fish in March to 16 point/fish in July. The feeding activity of the species ranged from $30 \%$ in February to $91 \%$ in April. In general, both feeding were low during winter and high during summer.

Monthly changes in the relative importance index $(I R I \%)$ of food items of $C$. auratus are shown in 
Figure 8. Algae came first position in order of relative importance in diet of the species, and varied from $15.1 \%$ in October to $93.9 \%$ in November. Macrophytes occupied the second position and ranged from $1.0 \%$ in November to $38.8 \%$ in April. Diatoms were occupying the third position and ranged from $1.1 \%$ in January to $50.3 \%$ in October. The contribution of crustacean in the diet fluctuated from $1.7 \%$ in April to $9.0 \%$ in October. Finally, aquatic insects ranged between $0.2 \%$ in March to $19.3 \%$ in October. The overall diet composition of C. auratus was comprised of algae $(52.6 \%)$, macrophytes $(22.0 \%)$, diatoms $(15.8 \%)$, crustacean $(4.8 \%)$ and aquatic insects $(4.8 \%)$.

\section{DISCUSSION}

The non-native species in an ecosystem is always likely to present an ecological risk if the species is able to integrate itself successfully into the ecosystem (Gozlan et al., 2010). C. auratus is well established in Al-Diwania river and considered the most dominated species constituted $14.6 \%$ of the fish population (Mohamed and Al-Jubouri, 2017). As it can be seen from the results, the size of $C$. auratus in the present study was larger than the range of the total length of the species reported from some other waters, such as $6.2-25.5 \mathrm{~cm}$ in Euphrates River at Al-Mussaib Power Station (Abbas et al., 2008), 9.0-21.5cm in Al-Hilla river (Al-Amari, 2011), 13.0-26.6 cm in Al-Tharthar arm, Tigris river (Wahab, 2013) and 8.3-28.0 in Euphrates river at Al-Hindyah Barrier (Khaddara, 2014), while it was within the range documented in some waters, like in East Hammar marsh, 2.0$31.0 \mathrm{~cm}$ (Al-Noor, 2010) and 13.0-30.0 cm (Mohamed er al, 2017), and was lower than those reported by Lorenzoni et al. (2010) and Gurung et al. (2018).

Length-weight relationship of fish is important in fisheries and fish biology because they allow the estimation of the weight of individual fish from its length, to calculate condition indices, to compare life history and morphology of populations belonging to different regions, to predict weight from length measurements made in the yield assessment (Sani et al., 2010; Singh et al., 2011). The regression coefficient $b$ in the length-weight relationship calculated for the species in the river was 3.129 , which indicates positive allometric growth. Positive allometric growth implies the fish becomes relatively stouter or deeper bodied as it increases in length (Riedel et al., 2007). Several authors have reported both isometric and allometric growth for $C$. auratus from various water bodies. The value of slope coefficient $(b)$ for the species was reported to be 2.927 in Wanghu Lake, china (Zhonghua et al., 1994), 2.890 in Euphrates River (Abbas et al., 2008), 3.062 in Lake Trasimeno, Italy (Lorenzoni et al. 2010), 2.830 in Corbara Reservoir (Pedicillo et al. 2007), 2.987 in East
Hammar marsh (Al-Noor, 2010), 3.212 in Al-Hilla river (Al-Amari, 2011), 3.000 in Derbendikhan reservoir (Rasheed, 2012), 3.092 in Tigris River (Wahab, 2013), 2.970 in Euphrates river at AlHindyah Barrier (Khaddara, 2014), 2.6392 in Guohe River, China (Wan et al., 2015) and 3.085 in the Esat Hammar marsh (Mohamed et al., 2016). These variations could be attributed to differences in size

range of fish, degree of stomach fullness, sex, age, disease and parasite loads, major change in environment factors and stage of maturity (Isa et al., 2010; Karma et al., 2012; Cuadrad et al., 2019)

The condition factor in fish serves as a measure of the physiological state of fish in relation to their health, and reflects physical and biological circumstances and fluctuations by interaction among feeding conditions, parasitic infections and reproductive cycle (Narejo et al., 2002; De Giosa et al., 2014). The general pattern of relative condition factor of $C$. auratus was low during autumn and high during spring. By overlaying seasonal changes of the relative condition factor with those of the gonado-somatic index, a similarity can be noticed between these patterns in the investigated species, there exists a relationship between relative condition factor and gonado-somatic index of both sex of the species. These results show similarities with Al-Noor (2010) in East Hammar marsh. He mentioned that the fluctuation in relative condition factor values of $C$. auratus during the period from June to October coincided with the variation in the gonado-somatic index values. The data showed a peak in February when the fish were in pre spawning period while the minimum value was in November during post spawning period.

The age composition of $C$. auratus population inhabiting the Al-Diwaniya river was ranged from 1 to 5 years. Similar age results were reported for the Lake Trasimeno to be 5 years old (Lorenzon et al., 2010). The age composition of C. auratus populations in previous studies was as follows: Wanghu Lake, 1-6 (Zhonghua et al., 1993), Euphrates River, 1-4 (Abbas et al., 2008), East Hammar marsh, 1-7 (Al-Noor, 2010), Al-Hilla river, 1-4 (Al-Amari, 2011), Euphrates river at Al-Hindyah Barrier, 1-6 (Khaddara, 2014), East Hammar marsh, 1-6 (Mohamed et al., 2016). This can be because of fishing pressure and sampling method. The growth rate and the theoretical growth in length $(L \infty)$ of $C$. auratus in Al-Diwaniya river were compared with other studies on the same species elsewhere (Table 2). It can be seen that the growth of the species in the present study showed higher growth rate than those documented by $\mathrm{Ab}$ bas et al. (2008), Al-Noor (2010) and Mohamed et al. (2017) during the first year of its life. Late, the growth of the species in Lake Trasimeno was the 
highest. The value of $L \infty$ of $C$. auratus was similar to that recorded for the species by Lorenzon et al. (2010) and Mohamed et al. (2017), but better than that recorded for the species in the other waters (Table 2). Therefore, the growth performance in$\operatorname{dex}(\Phi)$ of the species in the present study (2.612) was almost equal to the value (2.702) mentioned by Lorenzon et al. (2010). The growth that an individual fish achieves depends on three constraints, the genetic constitution of the individual, the abiotic environment experienced by the fish will set constraints on growth and the biotic environment will determine the extent of the growth potential that the fish can achieve as defined by its genotype and the abiotic environment experienced (Wootton, 2011).

The overall sex ratio of $C$. auratus in the present study was unbalanced in favor of females $(1: 3.81)$. Similar deviations in the sex ratio have been observed in many $C$. auratus populations. Lorenzoni et al. (2007) stated that the C. auratus population in Lake Trasimeno, Italy was composed mostly of females (sex ratio: $1: 19$ ) and the ratio attained 1:29 during the reproduction in May. Also, the ratio between the sexes of $C$ auratus in East Hammar marsh, Iraq was poised mostly of females, the sex ratio was 1:14.8 (Mohamed et al., 2016). The predominance of females are common in C. auratus populations and confirmed by the relevant literature (Lorenzoni et al., 2010; Jassim, 2012; Pandia, 2012; Wan et al., 2015). These populations are made up exclusively of females that reproduce by gynogenesis through mitotic divisions of eggs due to heterologous species of sperm (Vetemaa et al., 2005; Grabowska and Przybylski, 2015).

According to results of the gonado-somatic index $(G S I)$, we found that the reproductive period of $C$. auratus in present study extends over an ample time period, from March until September. Similar result was observed for this species by Al-Noor (2010) and Mohamed et al. (2016) in East Hammar marsh. Al-Noor (2010) stated that the monthly changes in gonad weight of $C$. auratus in East Hammar marsh take place during maturation cycle, which increased into a peak in February, then the weight decreased gradually during MarchSeptember, which may indicate that the release of oocytes is somewhat lengthy, and the fluctuation in GSI value coincided with proportion of fish in the different maturity stages to determine the spawning season. Lorenzoni et al. (2010) mentioned that spawning of $C$. auratus in Lake Trasimeno, Italy occurred from March to June and suggested that it is multiple spawned. The seasonal trend in the feeding activity of $C$. auratus in the present study is related with water temperature $(r=0.928)$, the highest value of the criterion was recorded in summer and the lowest one in winter. During this study, water temperature of the river varied from $10.2^{\circ} \mathrm{C}$ in March to $32.8^{\circ} \mathrm{C}$ in August (Mohamed and Al-Jubouri, 2017). Also, it is clear that the trend of feeding intensity almost resembles that of the feeding activities. It is generally known that feeding activity of Cyprinids decreases with decreasing of the water temperature (Penttinen and Holopainen 1992).

The results of the present study showed that $C$. auratus is herbivorous feeding habit, fed mostly on algae, macrophytes and diatoms which together making up $90.4 \%$. Several scientists studied the feeding habit of $C$. auratus in different parts of Iraqi water bodies and reported its herbivorous (Hussain et al., 2008; Lazem, 2009; Al-Noor, 2010; Mohamed and Hussain, 2012; Wahab, 2013; Mohamed and Abood, 2018). In contrast, other authors have stated that $C$. auratus was omnivores species (Saud, 2006; Al-Shamma'a et al., 2009; Mohamed et al., 2015). However, Specziár et al. (1998) mentioned that C. auratus was detritivors and zooplanktivors in Lake Balaton, Hungary, along the stony shoreline and in the reed grass stands, detritus dominated in their diet, and in the open water areas the species was planktivorous, consuming copepods and cladocerans. Rybczyk (2006) found that the highest contributions of the food items of $C$. auratus in Polish waters were those of ostracods and cladocera. Wahab (2013) reported that C. auratus in Tigris River, Iraq fed on detritus, macrophytes, algae, crustacean and aquatic insect. The ontogenetic change in diet of fish may be due to an interaction of changes in external factors such as habitat, food supply and predation risk, and internal conditions like anatomical structures, behavior and physiological demands (Luczkovich et al., 1995; Persson and Hansson, 1999; Specziár and Erős, 2014). Our results highlighted basic biological aspects of the invasive $C$. auratus which can assist in fisheries management and conservation of the fish species in Al-Diwaniya river.

\section{Conclusion}

The study revealed that the invasive $C$. auratus is well established in Al-Diwaniya river and attained large sizes. The growth in length $\left(L_{\infty}\right)$ was higher than that observed in other Iraqi waters. It is observed that seasonal changes in condition factor were positively correlated with the gonads development rather than the feeding activities. The sex ratio proved to be extremely unbalanced, in favor of females, and the reproductive season extended over an ample time period. The species was herbivorous, fed chiefly on a plant sources and thus compete the native economic species such as $M$. sharpeyi. Therefore, to prevent its distribution and influence on the native species, its biological characteristics should be monitored at regular intervals in the locality. 


\section{REFERENCES}

1. Abbas LM, Al-Rudainy LJ, Mohamed ARM and Hussain TS. (2008). Some biological aspects of the gold fish Carassius auratus (L. 1758) in the Euphrates River, middle of Iraq. Iraqi J. Agric., 13(1): 61-70.

2. Abbas LM, Abu-Elhine AJ, Radhy AG and Hassan AH. (2017). Evaluating the Fish Structure Community at Euphrates River near Al-Hindyah Barrier, Babylon Province/ Iraq. Journal Tikrit University For Agriculture Sciences, 17: 28-29.

3. Al-Nasiri SK and Shamsul Hoda SM. (1976). A guide to the freshwater fishes of Iraq. Bull. Basrah Nat. Hist. Mus. Publ., No.1: 126pp.

4. Al-Noor SS. (2010). Population status of gold fish Carassius auratus in restored East Hammar Marsh, Southern Iraq. JKAU: Mar. Sci., 21(1) : 65-83.

5. AL-Rudainy AJ, Mohamed ARM and Abbas LM. (2006). Ecology, Biology and Assessment of Fish Community in Euphrates River near Al-Mussaib Power Station. Euro Arab Environment Conference and Exhibition, 11: 27-29.

6. Al-Amari MJY. (2011). Study of some biological and ecological aspects of fish community in Al-Hilla River/ Iraq. College of Science, University of Babylon, Iraq.

7. Al-Shamma'a AA, Shawardy AO, Hassan AF and Nashaat MR. (2009). Natural diet of four fish species from the Euphrates River at Ash-Shamiyah, Iraq. Alanbar University Journal for Pure Science, 3(3): 74 $-82$.

8. Al-Shami IJ. (2008). Fecundity of Carassius auratus (Linnaeus, 1758) and histological description for its ripe ovaries in Garmat Ali River. Basrah J. Agric. Sci., 21(2) : 156-166.

9. Bagenal TB and Tesch FW. (1978). Age and growth. In: Methods for assessment of fish production in freshwater (Bagenal TB. Ed.). Blackwell Sci. Inc, 101 $-130$.

10.Coad WB. 2010 .Freshwater Fishes of Iraq. Pensoft Publishers, Sofia, Bulgaria.

11.Cuadrad JT, Lim DS, Alcontin RMS, Calang JL and Jumawan JC. (2019). Species composition and length-weight relationship of twelve fish species in the two lakes of Esperanza, Agusan del Sur, Philippines. FishTaxa, 4(1): 1-8.

12.De Giosa M, Czerniejewski P, Rybczyk A. (2014). Seasonal changes in condition factor and weight length relationship of invasive Carassius gibelio (Bloch, 1782) from Leszczynskie Lakeland, Poland. Advances in Zoology, 2014: 1-7.

13.De Silva SS. (1973). Aspects of the reproductive biology of the sprats Sprattus sprattus L. in inshore waters of the west coast of Scotland. J. Fish Biol., 5: 689-705.

14.Gozlan RE, Britton JR, Cowxi G, Copp GH. (2010). Current understanding on non-native freshwater fish introductions. J. Fish Biol., 76 (4): 751-786.

15.Grabowska J, and Przybylski M. (2015). Life-history traits of non-native freshwater fish invaders differentiate them from natives in the Central European bioregion. Rev. Fish Biol. Fisheries, 25: 165-178.

16.Gurung S, Bohara K, Adhikari R, Bista A and Singh S. (2018). Growth performance and feeding efficiency of goldfish (Carassius auratus) and red cap oranda fish (Carassius auratus auratus) by using different locally prepared feed mixed with different plant extracts at Paklihawa, Nepal. Journal of the Institute of Agriculture and Animal Science, 35: 277-284.
17. Hussain NA, Saoud HA and Al-Shami EJ. (2008). Trophic pyramids and food habits of five Cyprinid fish species in the southern restored Iraqi marshes during2004-2005. Basrah J. Agric. Sci., 21: 17-36.

18. Hussain NA, Mohamed ARM, Al-Noor SS, Mutlak FM, Abed IM and Coad BW. (2009). Structure and ecological indices of fish assemblages in the recently restored Al-Hammar Marsh, Southern Iraq. Bio Risk, 3: 173-186.

19. Hyslop EJ. (1980). Stomach contents analysis -a review of method and their application. J. Fish Biol., 17: 413-422.

20.Isa MM, Rawi CS, Rosla R, Shah SAM and Shah ASR. (2010). Length-weight relationships of freshwater fish species in Kerian River Basin and Pedu Lake. Research Journal of Fisheries and Hydrobiology, 5 (1): 1-8.

21.Jassim FK. (2012). Seasonal changes in maturity stage female and hermaphrodite gonad of goldfish Carassius auratus auratus (Linnaeus, 1758). Barah J. Agric. Sci., 25(1): 110-123.

22.Karma SK, Sahool D and Panda S. (2012). Length weight relationship (LWR), growth estimation and length at maturity of Etroplus suratensis in Chilika Lagoon, Orissa, India. International Journal of Environmental Sciences, 2: 1257-1267.

23.Khaddara MM. (2014). Ecological and biological study of fish community in Ephrates River/Middle of Iraq. PhD thesis, College of Science, University Babylon, Iraq.

24.Lazem LF. (2009). Ecological Evaluation of the Shatt Al-Arab River by Applying Geographical Information System (GIS). PhD thesis, College of Agriculture, Basrah University, Basrah, Iraq

25.Le Cren ED. (1951). The length-weight relationship and seasonal cycle in gonad weight and condition in the perch (Perca fluviatilis). J. Anim. Ecol., 20: 201219.

26.Lorenzoni M, Corboli M, Ghetti L, Pedicillo $G$ and Carosi A. (2007). "Growth and reproduction of the goldfish Carassius auratus: a case study from Italy. In: Biological invaders in inland waters: profiles, distribution and threats (Gherardi F. Ed.)." Springer Book, Berline, 259-273.

27.Lorenzoni M, Ghetti L, Pedicillo G and Carosi A. (2010). Analysis of the biological features of the goldfish Carassius auratus auratus in Lake Trasimeno (Umbria, Italy) with a view to drawing up plans for population control. Folia Zool., 59(2): 142-156.

28.Luczkovich JJ, Norton SF and Grant Gilmore R Jr. (1995). The influence of oral anatomy on prey selection during the ontogeny of two percoid fishes, Lagadon rhomboides and Centropornus undecimalis. Environ. Biol. Fishes, 44: 79-95.

29. Mohamed ARM, Hussein SA and Mutlak FM. (2016). Stock Assessment of four fish species in East Hammar marsh, Iraq. Asian J. Appl. Sci., 4(3): 620627.

30.Mohamed ARM, Hussein SA and Mutlak FM. (2017). Some biological aspects of Four Fish Species in East Hammar Marsh, Iraq. J. Sci. Eng. Res., 4(8): 278287.

31.Mohamed ARM and Al-Jubouri MOA. (2017). Fish assemblage structure in Al-Diwaniya River, middle of Iraq. Asian J. Nat. Appl. Sci., 6(4): 10-20.

32.Mohamed ARM, Hussein SA and Mutlak FM. (2015). The feeding relationships of six fish species 
in East Hammar marsh southing Iraq. Thi-Qar Univ J. Agric., 4(1): 460-477.

33.Mohamed ARM and Hussain NA. (2012). Trophic strains and diet shift of the fish assemblages in the recently restored Al-Hammar marsh, southern Iraq. J. University of Duhok, 15(1): 115-127.

34.Mohamed ARM Hussain NA Al-Noor SS and Mutlak, F.M. (2012). Ecological and biological aspects of fish assemblage in the Chybaish marsh, Southern Iraq. Ecohydrology \& Hydrobiology, 12(1): 65-74.

35.Mohamed ARM, Hussain NA, Al-Noor SS, Coad BW, Mutlak FM, Al-Sudani IM, Mojer AM and Toman AJ. (2008). Species composition, ecological indices and trophic pyramid of fish assemblage of the restored $\mathrm{Al}$ -Hawizeh Marsh, Southern Iraq. Ecohydrology \& Hydrobiology, 8(2-4): 375-384.

36. Mohamed ARM. and Abood AN. (2018). Diet and trophic status of three cyprinids fish in the Shatt AlArab River, Iraq. J Agric. Vet. Sci., 11(7): 49-57.

37.Narejo NT, Rahmatullah SM and Mamnur M. (2002). Length-weight Relationship and Relative condition factor $(K n)$ of Monopterus cuchia (Hamilton). Indian J. Fish., 8: 54-59.

38.Pandia TJ. (2012). Genetic Sex Differentiation in Fish. CRC Press, Taylor \& Francis Group, LLC.

39.Pauly D and Munro JL. (1984). Once more on the comparison of growth in fish and invertebrates. ICLARM Fish byte, 2, 21.

40.Pedicillo G, Bicchi A, Angeli V, Carosi A, Viali P and Lorenzoni M. (2007). Growth and reproductive biology of Carassius auratus (Linnaeus, 1758) in the Corbara Reservoir (Umbria - Italy). FSBI 2007 Annual International Symposium, Exeter 23-27 July: 34.

41.Penttinen OP and Holopainen IJ. (1992). Seasonal feeding activity and ontogenetic dietary shifts in crucian carp, Carassius carassius. Envir. Biol. Fish., 33: 215-221.

42.Persson A and Hansson LA. (1999). Diet shift in fish following competitive release. Canadian J. Fish. Aquat. Sci., 56: 70-78.

43.Rasheed RO. (2012). Length-Weight relationships of (9) fish species from Derbendikhan ReservoirKurdistan region, Iraq. J. Babylon University/Pure Appl. Sci., 20(5): 1434-1440.

44.Ricker WE. (1975). Computation and interpretation of biological statistics of fish populations. Bull. Fish. Res. Board. Can., 191: 382 p.

45.Riedel R, Caskey LM and Hurlbert SH. (2007). Length-weight relations and growth rates of dominant fishes of the Salton Sea: implications for predation by fish-eating birds. Lake and Reservoir Management, 23: $528-535$.

46.Rybczyk A. (2006). Selected Aspects of Biological
Characteristics of The Prussian Carp (Carassius auratus gibelio Bloch, 1783): Food, Feeding, And Condition. Acta Scientiarum Polonorum, Piscaria, 5 (2): 69-82.

47.Sani R, Gupta BK, Sarkar UK, Pandey A, Dubey VK and Lakra WS. (2010). Length weight relationship of 14 Indian freshwater species from river Betwa (Yamuna River tributary) and Gomti (Ganga river tributary). J. App. Ichthyol., 26: 456-459.

48.Saud HA. (2006). Study of feeding habits of the crucian carp Carassius auratus L. in marshes of southern Iraq. Basrah J. Agric. Sci., 19(1): 141-155.

49.Schneider JC, Laarman PW and Gowing H. (2000). Age and growth methods and state averages. Chapter 9 In: Manual of fisheries survey methods II: with periodic updates. Michigan Department of Natural Resources. Fisheries Special Report 25, Ann Arbor. Schneider, James C. 2000.

50.Singh NO, Sarma D, Singh NG. (2011). Lengthweight relationship of Tor putitora (Hamilton) from Kosi River Uttarakhand considering different stages of its lifespan. Indian J. Fish., 58: 35-38.

51.Specziár A, Bíró P and Tölg L. (1998). Feeding and competition of five cyprinid fishes in different habitats of the Lake Balaton littoral zone, Hungary. Italian J. Zool., 65: 331-336.

52.Specziár A and Erős T. (2014). Dietary variability in fishes: the roles of taxonomic, spatial, 2 temporal and ontogenetic factors. Hydrobiologia, 724: 109-125.

53.Stergion KI. (1988). Feeding habits of the lessepsian migrant Siganus luridus in the Eastern Mediternian, its new environment. J. Fish Biol., 33: 531-543.

54.Vetemaa M, Eschbaum R, Albert A and Saat T. (2005). Distribution, sex ratio and growth of Carassius gibelio (Bloch) in coastal and inland waters of Estonia (north-eastern Baltic Sea). J. Appl. Ichthyol. 21: 287-291.

55.Wahab NK. (2013). Food habits and diet overlaps for some freshwater fish in Tharthar Arm, Tigris, Iraq. Basrah J. Agric. Sci., 26(2): 182-197.

56.Wan A, Yu S, Hu J, Wan Y, Wei Y, Zhong M, Yang H, An S and Yan Y. (2015). The Age, Growth, Fecundity of Carassius auratus in. , the Guohe River of Guoyang County. Clean Soil Air Water, 45: 676-682.

57.Wootton R.J. (2011). "Growth: environmental effects. In: Encyclopedia of fish physiology: from genome to environment (Farrell AP, Ed.)." Elsevier Science Publishing Co. Inc, United States, 1629-1635.

58.Zhonghua D, Jianyi S, Jianbo C, Yang X, Decqing $T$ and Zhiguo M. (1994). The growth and stock assessment of Carassius auratus L. in Wanghu Lake. J. Lake Sci., 6(3): 257-266. 